\title{
Tinjauan Perspektif Iman Kristen tentang Mangadati dalam Pernikahan Masyarakat Batak Toba
}

\author{
Vera Herawati Siahaan ${ }^{1}$, Harlin Yasin ${ }^{2}$ \\ ${ }^{1,2}$ Sekolah Tinggi Agama Kristen Teruna Bhakti, Yogayakarta \\ verajasmin77@gmail.com ${ }^{1}$,yasinharlin@gmail.com ${ }^{2}$
}

\begin{abstract}
The Toba Batak traditions in terms of "mangadati" carry out traditional Batak Toba cultural events that adhere to the exogamy law, namely marriages outside certain ethnic groups. This is seen in the Batak Toba community where people do not take wives from the clan group themselves (namariboto), because they are called siblings; women leave their groups and move to the husband's group, and are patrilineal, with the aim of preserving the husband's clan within the male line. This article uses the method of phenomenological analysis with a biblical reflection approach. Mangadati marriage custom from the perspective of Christian faith is not a contradiction, because the custom is done with love, the value of respect and the value of brotherhood and togetherness in accordance with Matthew 22: 37-40.
\end{abstract}

Keywords: Batak custom; Batak's marriage; mangadati

\begin{abstract}
Abstrak: Adat Batak Toba dari sisi "mangadati" melaksanakan acara adat kebudayaan Batak Toba yang menganut hukum eksogami, yaitu perkawinan di luar kelompok suku tertentu. Ini terlihat dalam masyarakat Batak Toba di mana orang tidak mengambil isteri dari kalangan kelompok marga sendiri (namariboto), karena disebut kakak-adik; perempuan meninggalkan kelompoknya dan pindah ke kelompok suami, dan bersifat patrilineal, dengan tujuan untuk melestarikan marga suami di dalam garis lelaki. Artikel ini menggunakan metode analisis fenomenologi dengan pendekatan refleksi biblikal. Adat pernikahan mangadati ditinjau dari perspektif iman kristen bukan suatu yang bertentangan, karena adat dilakukan dengan kasih, nilai hormat dan nilai persaudaraan serta nilai kebersamaan sesuai dengan Matius 22: 37-40.
\end{abstract}

Kata kunci: adat Batak; mangadati; pernikahan Batak

\section{Pendahuluan}

Sejarah orang Batak atau latar belakang masyarakat Batak Toba adalalah memakai bahasa Austronesia namun tidak diketahui kapan nenek moyang orang Batak pertama kali bermukim di Tapanuli dan Sumatera Timur. Bahasa dan bukti-bukti arkeologi menunjukkan bahwa orang yang berbahasa Austronesia dari Taiwan telah berpindah ke wilayah Filipina dan Indonesia sekitar 2.500 tahun lalu. Zaman Batu Muda (Neolitikum), hingga sekarang belum ada artefak Neolitikum yang ditemukan di wilayah Batak. Dapat diduga nenek moyang Batak baru bermigrasi ke Sumatera Utara di Zaman Logam pada abad ke-6. ${ }^{1}$ Pedagang-pedagang Tamil asal India mendirikan kota dagang Barus, di pesisir barat Sumatera Utara. Berdagang kapur barus yang diusahakan oleh petani-petani di pedalaman. Kapur barus dari tanah Batak bermutu tinggi sehingga menjadi salah satu komoditas

${ }^{1}$ www.wikipidia Batak dan Budayanya 
ekspor di samping kemenyan, pada abad ke-10 Barus diserang oleh Sriwijaya. Hal ini menyebabkan terusirnya pedagang-pedagang Tamil dari pesisir Sumatera. Pada masa-masa berikutnya, perdagangan kapur barus mulai banyak dikuasai oleh pedagang Minangkabau yang mendirikan koloni di pesisir barat dan timur Sumatera Utara. Koloni-koloni terbentang dari Barus, Sorkam, hingga Natal.

Terbentuknya masyarakat Batak yang tersusun dari berbagai macam marga. Sistem kekerabatan orang Batak adalah patrilineal menurut garis keturunan ayah. Garis keturunan laki-laki di teruskan oleh anak laki-laki kemudian anak laki-laki menikah memiliki keturunan laki-laki, demikian seterusnya. ${ }^{2}$ Selain itu sebagian disebabkan karena adanya migrasi keluarga-keluarga dari wilayah lain di Sumatra. Penelitian penting tentang tradisi Karo dilakukan oleh J.H Neuman, berdasarkan sastra lisan dan transkripsi dua naskah setempat, yaitu Pustaka Kembaren dan Pustaka Ginting. Menurut Pustaka Kembaren, daerah asal marga Kembaren dari Pagaruyung di Minangkabau. ${ }^{3}$ Orang Tamil diperkirakan juga menjadi unsur pembentuk masyarakat Karo. Hal ini terlihat dari banyaknya nama marga Karo yang diturunkan dari Bahasa Tamil.

Penelitian tentang budaya yang dikaitkan dengan iman Kristen bukanlah hal yang langka ${ }^{4}$, terutama budaya di daerah-daerah yang mayoritas Kristen. Hal ini terkait dengan agama yang dianut dan dijalankan tidak jarang dianggap berbenturan dengan kebiasaan sehari-hari yang sudah mendarah daging dalam kehidupan para penganut agama tersebut. Termasuk dalam hal ini adalah budaya Batak, di mana ada banyak kebiasaan atau tradisi yang masih dipertahankan dan dijalankan oleh orang Kristen dari Batak yang kemudian memunculkan pro dan kontra di kalangan orang-orang Batak yang beragama Kristen. Sebagai contoh apa yang dilakukan oleh Togar Nainggolan, yang mencari sebuah titik temu antara budaya Batak dan kekristenan. ${ }^{5}$ Dialog antar budaya dan agama selamanya akan selalu dilakukan demi menemukan keselarasan, di mana seorang yang beriman tidak perlu meninggalkan budayanya.

Dalam budaya Batak ada hal-hal yang coba dipertentangkan dengan iman Kristen, seperti praktik gondang dan tortor yang masih wajar untuk dilakukan oleh gereja. ${ }^{6}$ Atau, budaya Mangongkal Holi yang terkenal di kalangan keluarga Batak, juga telah mendapat perhatian dalam penelitian yang dikaitkan dengan iman Kristen. ${ }^{7}$ Ada gereja yang dapat menerima perayaan dengan adat dan tradisi dipadu ibadah kristiani sebagai upaya gereja melestarikan budaya dan kearifan local. Sementara itu, ada juga yang menolak dengan

\footnotetext{
${ }^{2}$ J. C. Vergouwen, Masyarakat dan Hukum Adat Batak Toba, (Jakarta: Pustaka Azet,1985), 23.

${ }^{3}$ JH Neuman, Pustaka Kambaren, 34.

${ }^{4}$ Pilemon Bukit, "Pandangan Kristen Tentang Kebudayaan Dan Adat Istiadat Di Dalamnya," SOTIRIA (Jurnal Theologia dan Pendidikan Agama Kristen) 2, no. 1 (2019): 1-15.

${ }^{5}$ Togar Nainggolan, “Adat Dan Iman Kristen Di Tanah Batak,” Jurnal Filsafat-Teologi 5, no. 1 (2007): 75-93.

${ }^{6}$ Mauly Purba, “Gereja Dan Adat: Kasus Gondang Sabangunan Dan Tortor,” Antropologi Indonesia 62, no. 1 (2014): 25-41.

${ }^{7}$ Firman Oktavianus Hutagaol and Iky Sumarthina P. Prayitno, "Perkembangan Ritual Adat Mangongkal Holi Batak Toba dalam Kekristenan di Tanah Batak (The Development of the Mangongkal Holi Batak Toba Indigenous Ritual in Christianity in the Batak Land)," Anthropos: Jurnal Antropologi Sosial dan Budaya 6, no. 1 (2020): 84-92.
} 
menganggapnya sebagai upaya sinkretisme. Penelitian ini mengkaji sebuah tradisi yang masih dilakukan oleh orang Batak ketika menikah dengan orang yang di luar suku Batak, yakni mangadati. Penelitian tentang pernikahan adat Batak yang telah dilakukan oleh Destien Mistavakia Sirait dan Dasrun Hidayat memokuskan pada praktik memberikan ulos, atau mengulosi. ${ }^{8}$ Kajian tentang pernikahan dengan praktik mangadati belum dibahas secara spesifik dalam kaitannya dengan perspektif iman Kristen. Itu sebabnya hal ini menjadi tujuan dalam pembahasan penelitian ini.

\section{Metode Penelitian}

Metode penelitian yang digunakan adalah survei yang bersifat penjelasan-penjelasan (eksplanatori) dan juga berupa penelitian atau pengujian secara langsung di lapangan (konfirmatori), yaitu pelaku adat pernikahan adat Batak Toba yaitu mangadati di kota Yogyakarta. Penelitian ini juga berupa penjelasan atau wawancara yang didapatkan dari masyarakat Batak Toba yang ada di Yogyakarta untuk menemukan dampak mangadati bagi kehidupan sosial masyarakat Batak Toba. Inti permasalahan yang menjadi hambatan dalam penerimaan ketika tidak melakukan adat mangadati. Metode deskriptif digunakan untuk memberikan gambaran tentang praktik mangadati yang akan dikaitkan dengan iman Kristen. Sebelum dipandang dari perspektif iman Kristen, penting untuk mendeskripsikan variabel mangadati itu sendiri; apa tujuan dan mekanismenya.

\section{Tujuan Mangadati dalam Adat Batak Toba}

Banyaknya padangan dan pengertian mengenai adat mangadati dalam pernikan Batak Toba, mealui karya tulisan, buku, media cetak dan juga pelatihan-pelatihan pelaksanaan mangadat, pengamatan langsung dan mempraktekkan langsung acara mangadati membuat pandangan yang berbeda-beda dari setiap pelaku adat tersebut. Acara ini memiliki tujuan yang sama supaya dikatakan pelaku adat yang menghormati adat dan melakukan adat serta melestarikan adat. Mangadati dalam pernikahan adat Batak Toba merupakan suatu acara adat. Anggapan acara perkawinan adat dan pelaksanaa adat rumit dan bertele-tele adalah keliru, sepanjang acara adat itu diselenggarakan sesuai pemahaman dan nilai luhur adat itu sendiri. Adat tersebut menjadi rumit dan bertele-tele karena diselenggarakan sesuai pamaham atau selera tertentu. Artinya acara adat bisa dilakukan dengan tujuan menghormati sesama kerabat atau keluarga.

Komunikasi antara kedua belah pihak akan menenetukan proses pernikhan adat tersebut, karena asal usul adat itu telah di tentukan genealogis maka mengawinkan anak laki-laki dan perempuan menjadi titik puncak yang sesungguhnya. ${ }^{9}$ Perkawinan pada masyarakat Batak bukan hanya mengikat seorang laki-laki dengan seorang wanita, melainkan juga mengikat suatu hubungan tertentu, kaum kerabat dari mempelai laki-laki paranak dengan kaum kerabat mempelai wanita parboru. ${ }^{10}$

\footnotetext{
${ }^{8}$ Destien Mistavakia Sirait and Dasrun Hidayat, "Pola Komunikasi Pada Prosesi Mangulosi Dalam Pernikahan Budaya Adat Batak Toba,” Jurnal Ilmu Komunikasi 2, no. 1 (2016): 23-31.

${ }^{9}$ Schreiner, Adat dan Injil, 15.

${ }^{10}$ Koentjaraningrat, Manusia dan Kebudayaan di Indonesia (Jakarta: Djambatan, 1985), 102
} 
Aturan pernikahan dalam adat Batak harus didasarkan pada falsafah Dalihan natolu; istilah ini merupakan tiga golongan fungsional yang berbeda antara lain adalah: Hula-hula, dongan sabutuha, boru. Ketiga ini mewakili dunia bawah, tengah dan atas ${ }^{11}$, dan diperlukan dalam acara mangadati. Ketiga unsur tersebut yang dalam bahasa Batak disebut dalihan natolu memiliki pengertian secara literal: satuan tungku tempat memasak yang terdiri dari tiga batu. Setiap keluarga selalu akan pernah menjadi posisi-posisi ketigannya. Tergantung siapa yang melakukan adat, keluarga tersebut akan pernah menjadi hula-hula, akan pernah menjadi teman pelaku adat dan jika keluarga istri yang melakukan adat akan pernah menjadi pihak boru.

Pada zaman dahulu, kebiasaan masyarakat Batak memasak di atas tiga tumpukan batu, dengan bahan bakar kayu. Tiga tungku itulah yang disebut dalam bahasa Batak dalihan, di mana falsafah dalihan na tolu dimaknai dengan kebersamaan, kerukunan yang cukup adil dalam kehidupan masyarakat Batak. Oleh sebab itu sangat diharapkan pelaksanaan mangadati membuat suatu kesatuan dan kebersamaan dengan sesama keluarga tanpa mengesampingkan status pelaksanaan adat tersebut. Tujuan mangadati adalah ketaatan, artinya jika taat maka kita akan mendapatkan apa yang namanya kebahagian. Tungku merupakan bagian peralatan rumah di dapur yang sangat penting karena digunakan untuk memasak makanan dan minuman sebagai sumber kehidupan bagi keluarga.

Pada umumnya kelompok orang Batak yang mendukung dan melakukan adat adalah mereka yang mengagungkan adat dan terus memengang nasehat leluhur menjadikan semua adat seolah-olah benar dan sempurna tanpa ada salah yang setara dengan kebenaran Firman Tuhan. ${ }^{12}$ Menurut S. R. Siahaan adat dan kekerabatan orang Batak diwarisi dari nenek moyang, sebagai pedoman atau petunjuk dalam menjalini kehidupan orang Batak, untuk mengatur hubungan dan perilaku antar manusia orang Batak agar kehidupannya berjalan dengan baik dan menyenangkan serta menuju kehidupan yang kekal. ${ }^{13}$ Demikian halnya dengan hukum adat yang berlaku untuk masyarakat suku Batak Toba, baik yang berada di daerah asal (bonapasogit) maupun yang berada di perantauan. Semua masyarakat Batak ingin melakukan adat dengan dalihan natolu. Pelaku adat diawali pernikahan adat yang disebut dengan mangadati.

Dengan demikian gambaran mangadati atau tujuan mangadati adalah awal melaksanakan adat lainnya, supaya bisa melakukan adat dalam kehidupan sosial budaya Batak. Bila perkawinannya sudah sah secara adat atau disebut mangadati. ${ }^{14}$ Mangadati memiliki unsur-unsur tradisional yang diwarisi merupakan harta yang sangat mahal dan perlu. Dalam hal ini disebut melestarikan adat salah satu tujuan mangadati, yang diturunkan oleh keturunan satu kepada keturunan selanjutnya. Oleh sebab itu sebagai orang yang memiliki

\footnotetext{
${ }^{11}$ Tobing O. L., Ph., The Structure Of The Toba - Batak Belief in The High God, (Jakarta: South and South- East Celebes Institute For Culture, Cet .3 1994), 148.

${ }^{12}$ Sagala Mangapul, Injil dan Adat Batak, (Jakarta: Yayasan Bina Dunia , Cet 2, 2008), 18.

${ }^{13}$ S.R. Siahaan. Aha do Adat I (Yogyakarta: 2012), 1.

${ }^{14}$ Richard Sinaga, Meninggal Adat Dalihan Natolu (Jakarta : Dian utama, 2003), 124.
} 
adat maka terbuka pintu untuk medapatkan kebenaran atau palsafah hidup orang Batak yang di sebut dengan tiga $\mathrm{H}$ : hagabeon, hasangapon, hamoraon.

Kuatnya memegang adat merupakan kebanggaan bagi orang Batak Toba, tentu saja hal ini sangat mempengaruhi kehidupan masyarakat Batak dalam kehidupan sehari-hari. Di samping itu juga karena adanya sangsi dalam hal sikap atau penerimaan maka ketika keluarga tidak melakukan adat mangadati meskipun sudah di berkati di gereja, sudah melakukan pernikahan catatan sipil namun belum melakukan pernikahan adat maka itu di sebut dengan hutang adat. Hutang adat yang akan terus ditagih dalam hal ini di sebut dengan sangsi moral terhadap sesama orang Batak dan juga keluarga besarnya. Adat istiadat Batak disebut dengan "ima ngolu hapantunon na niliggoman ni uhum dohot paraturan namasa atau namarlaku ditonga-tonga ni masyarakat, artinya adalah kehidupan bertatakrama yang dilindungi oleh hukum dan peraturan yang berlaku ditengah-tengah masyarakat Batak. ${ }^{15}$ Dengan demikian tujuan pernikahan adat masyarakat Batak Toba adalah: membahagian orang tua, memdapatkan penerimaan di tenga-tengah masyarakat batak, bisa melakukan adat Batak lainnya, mengasihi sesama orang Batak dan melestarikan adat peninggalan orang tua-tua dulu sehingga setiap keluarga yang melakukan adat pernikahan mangadati akan mendapatkan kebahagian yang sejati kebahagian dari sesama dan dari Tuhan melalui pasu-pasu atau berkat.

\section{Pernikahan Dalam Hukum Agama dan Adat Batak Toba}

Peraturan Perkawinan Campuran (Regelingop de gemengde Huweklijks S. 1898 No. 158), dan peraturan-peraturan lain yang mengatur tentang perkawinan sejauh telah diatur dalam Undang-Undang ini, dinyatakan tidak berlaku. ${ }^{16}$ Dengan berlakunya UU No. 1 Tahun 1974, maka semua warga negara harus tunduk dan taat pada ketentuan-ketentuan Undangundang tersebut. ${ }^{17}$ Namun karena Undang-Undang ini hanya bersifat pokok yang masih memerlukan peraturan pelaksanaan, maka di dalam pasal 66 UU No. 1 Tahun 1974 disebutkan: "Untuk perkawinan dan segala sesuatu yang berhubungan dengan perkawinan berdasarkan atas Undang-Undang ini, maka dengan berlakunya Undang-Undang ini ketentuan-ketentuan yang diatur dalam Kitab Undang-Undang Hukum Perdata. ${ }^{18}$

Hukum adat Batak Toba, khususnya perkawinan sangat memperhatikan prinsip dasar menyatakan kesatuan hubungan kekeluargaan pada suku Batak, serta perkawinan berpegang teguh pada prinsip ini, karena Dalihan Na Tolu tidak dapat dipisahkan dari hukum adat Batak Toba, bagian dari adat istiadat masyarakat adat Batak. ${ }^{19}$ Kekerabatan dalam Batak Toba menganut patrilineal (garis bapak), kekerabatan merupakan hal yang sangat penting bagi masyarakat adat Batak Toba, karena dengan adanya perkawinan maka seorang laki-laki dapat meneruskan marga ayahnya secara turun temurun.

\footnotetext{
${ }^{15}$ Siahaan, Aha Do Adat I, 2.

${ }^{16}$ E. Utrecht, Pengantar Dalam Hukum Indonesia (Jakarta: Pendidikan dan Balai Buku "Ichtiar", 1996), 84.

${ }^{17}$ Hadikusuma, Hukum Perkawinan Adat

${ }^{18}$ Burgerlijk Wetboek, Ordonasi Perkawinan Indonesia Kristen (Huwelijks Ordonatie Christen Indonesier S, 1933), 74.

${ }^{19}$ Ibid, 149.
} 
Perkawianan adat juga masih dipengaruhi oleh hukum agama yang berlaku di daerahnya karena dasar dari undang-undang perkawinan adalah hukum agama dan kepercayaan pihak-pihak yang melangsungkan perkawinan. Hukum adat yang dihormati dan ditaat oleh masyarakat khususnya masyarakat adat Batak Toba juga mengakui eksistensi hukum positif yang berlaku di negara Indonesia yang berkedaulatan rakyat yang berdasarkan hukum. Dengan demikian hukum agama dan kepercayaan yang dianut pihakpihak yang melangsungkan perkawinan merupakan unsur-unsur dari pada hukum adat. Hukum perkawinan adat sebagai hukum tidak tertulis dan beraneka berbagai kalangan masyarakat adat di Indonesia merupakan sumber yang penting pula dalam perkawainan yang besifat nasional. Bagi masyarakat Batak Toba yang melakukan pernikahan mangadati sangat tidak mungkin ada kesempatan pernikahan tersebut dapat dipisahkan oleh manusia.

Dalam menjalankan semua adat Batak, pelaku adatnya haruslah memperhatikan nasihat nenek moyang atau dalam bahasa Batak poda ni ompunta termasuk pelaksanaan adat pernikahan yang disebut dengan mangadati. Jolo diseat hata asa diseat raut (dibicarakan sebelum dilaksanakan adanya perencanaa yang matang atau persiapan musyawarah); Sidapot solup do na ro (mengikuti adat Batak setempat walau di perantauan); Aek Godang tu aek laut, dos ni roha nasaut (adanya musyawarah mufakat kepada pelaku adat). Pelaksanaan adat yang baik dan berkenan dan sah yaitu pelaksanaaan dengan Dalihan Natolu, yakni tiga tatanan adat Somba Marhula-hula, Manat mardongan tubu, elek marboru. Ketiga tatanan ini merupakan pembagian yang adil dan seimbang yang menjadi pedoman dalam kehidupan sosial sejak lahir, menikah bahkan sampai meninggal dunia. Ketiganya menjadi satu kesatuan yang tidak terpisahkan. Setiap orang Batak akan pernah menduduki ketiga posisi tersebut, tergantung konteks masing-masing.

Dengan demikian pernikahan secara hukum pemerintahan merupakan satu kesatuan yang tidak terpisahkan dari pernikahan adat, artinya sebelum terjadi pernikahan adat harus terjadi pernikahan pemerintahan, atau pernikahan gerejawi. Oleh sebab itu ada hubungan yang sangat erat antara adat dan pemerintahan. Jika sudah melakukan pernikahan adat maka ada aturan yang juga harus dilakukan supaya mendapat suatu yang terbaik kebahagian dengan melakukan hukum adat yang diakui sebagai lembaga pemersatu di antara keluarga sesama orang Batak Toba.

\section{Pembahasan}

\section{Perspektif Iman Kristen Menyoroti Acara MagadatiPernikahan Suku Batak Toba}

Hubungan persahabatan antara laki-laki dan perempuan dewasa memiliki tujuan yang mulia yaitu pernikahan. Pernikahan merupakan konsep Allah sejak manusia Adam dan Hawa diciptakan. Rencana Allah bagi lembaga pernikahan merupakan suatu rancangan yang direncanakan Allah kepada manusia. ${ }^{20}$ Pernikahan merupakan suatu anugerah indah, yang dialami oleh laki-laki dan perempuan. Tuhan Allah menciptakan alam semesta dan menjadikan manusia menurut gambar dan rupa Allah. Manusia adalah pemegang otoritas tertinggi atau di sebut mahluk teristimewa Allah, yang akan mengelola segala ciptaanya di

${ }^{20}$ Jonathan A Trisna, Pernikahan Kristen Suatu Usaha Dalam Kristus ((Jakata: Insititut keguruan Indonesia, 2000), 2. 
dunia. Melalui ikatan pernikahan yang kudus manusia akan beranak cucu dan memenuhi bumi serta terus menikmati hidup, mengelola, memelihara selama beberapa waktu didunia.

Pernikahan adalah sesuatu yang sangat terencana, artinya ada proses waktu yang tidak terbatas. Perkenalan merupakan awal persahabatan lalu kemudian memutuskan menikah. Pada saat menikah kedua calon mempelai akan membuat janji di hadapan Tuhan dan jemaat untuk hidup bersama baik dalam suka maupun dalam duka, dalam kelimpahan sampai maut yang memisahkan. Jika ditilik sebelum pelaksanaan pernikahnnya maka jelaslah bahwa pernikahan merupa proses pemilihan yang sesuai dengan hati dan persaan antara laki-laki dan perempuan. Untuk mengikat janji atau di sebut dengan mengikrarkan diri sehidup semati bersama dalam kehidupan bersama. Untuk memenuhi kebutuhan bersama dengan cinta kasih yang dianugerahkan Tuhan kepada kedua insan manusia tersebut. Semua peroses inilah rancangan yang ideal atau sempurna dari Tuhan untuk menjalani bahtera rumah tangga. ${ }^{21}$ Kehidupan berkeluarga adalah berkat yang diberikan oleh Allah kepada umat manusia. Artinya tulisan diatas menjelaskan kepada semua orang bahwa pernikahan itu tidak dapat dipisahkan oleh siapapun termasuk adat yang dipegang oleh pihak keluarga tertentu. ${ }^{22}$ Kata siapa pun di sini menjelaskan kepada semua orang bahwa tidak ada yang bisa memisahkan anugerah tersebut.

Dapat dipahami bahwa pernikahan dalam iman Kristen merupakan suatu hubungan yang dilakukan oleh laki-laki dan wanita dewasa dengan proses yang sudah dipersiapkan. Cinta yang dianugerahkan Tuhan merupakan kunci utama terjadinya hubungan. Pasangan yang memutuskan untuk menikah merupakan pasangan yang akan siap menghadapi hidup secara mandiri di tengah-tengah masyarakat. Oleh sebab itu, hendaknya anugrah yang Tuhan berikan menjadi barang berharga yang senantiasa di jaga dengan kesetian kepada pasangan dan kepada Tuhan.

\section{Pernikahan adalah Anugerah Allah}

Pernikahan merupakan tujuan dan rencana Allah, tujuan Allah menciptakan laki-laki dan perempuan salah satunya untuk pernikahan. Pertama kali manusia yang diciptakan Allah adalah seorang laki-laki yaitu Adam, lalu Ia menciptakan seorang wanita dari tulang rusuk Adam, yaitu Hawa, dan menjadikan mereka menjadi pasangan hidup. Demikian pula halnya dengan manusia selanjutnya, menjadi satu sebagai pasangan, karena keduanya merupakan pribadi-pribadi yang utuh. ${ }^{23}$ Bukan itu saja lembaga pernikahan tersebut menjadi media tertinggi dalam setiap keluarga. Tentunya, setiap keluarga memahami bahwa ini menjadi sesuatu yang sangan berharga.

Dalam Markus 10:8, 9 dijelaskan: "Sebab itu laki-laki akan meninggalkan ayah dan ibunya dan bersatu dengan istrinya sehingga keduanya menjadi satu daging. Demikianlah

\footnotetext{
${ }^{21}$ Paulus Lilik Kristianto, Prinsip dan Praktik Pendidikan Aagama Kristen ( Yogyakarta ANDI, 2006), 141.

${ }^{22}$ Volkard dan Gertindescheuneman, Hidup Sebelum Dan sesudah nikah (Malang: Yayasan Persekutuan Injil Indonesia Literatur 1978), 17-21.

${ }^{23}$ Friesen, Inikah Rasanya Jatuh Cinta (Yogyakarta: Gloria Grafa, 2006) , 21,22.
} 
mereka bukan lagi dua, melaikan satu. Karena itu apa yang sudah dipersatukan Allah tidak boleh diceraikan manusia." Pernyataaan tersebut menunjukkan sebab akibat: meninggalkan ayah dan ibu keluarga, untuk menjadikan keluarga baru. Meninggalkan tidak hanya melepaskan diri dari keluarga melainkan kesanggupan untuk membina rumah tangga bersama dengan seorang wanita yang dicintai. Meninggalkan merupakan langkah awal menuju sebuah bahtera pernikahan yang bahagia, mandiri meninggalkan secara alkitabiah meninggalkan orang tua supaya dapat mandiri secara matang baik secara emosi dan spritual. ${ }^{24}$ Walau pada awal pernikah perlu belajar, tidak bisa langsung mandiri, semua butuh waktu dan proses.

Allahlah yang menciptakan anugerah pernikahan manusia, oleh sebab itu Allahlah yang memberikan hikmat kepada manusia. Dimulai dari penciptaan Allah akan manusia pertama yaitu Adam, Allah kemudian menciptakan Hawa sebagai teman dan pasangan dan seorang pendamping bagi Adam. ${ }^{25}$ Jika pernikahan didasarkan atas anugerah, sudah jelas bahwa cinta, kasih, rasa tertarik dan ingin dimiliki merupan suatu yang Tuhan siapkan dengan kesiapan, kesepakatan, keinginan atau perjanjian. Pernikahan merupakan perjanjian untuk mencerminkan gambar Allah yang membuat perjanjian tersebut. Dalam kehidupan seringkali ada perjanjian antara sesama tetapi tidak sama dengan perjanjian kita pada saat pernikahan. Perjanjian pernikahan adalah perjanjian kedua mempelai kepada Tuhan dalam hal ini ketaatan kepada perjanjian Allah haruslah ada kesetiaan.

Dalam pernikahan perlu disadari oleh pasangan yang berniat akan menikah sudah selayaknya memilihi hubungan saling kasih yang sepadan, seimbang dan sejajar dalam kasih. Sehingga keduanya, baik laki-laki dan perempuan harus bisa saling memahami, melengkapi, melayani, menerima, memberi seorang dengan yang lainnya demikian saling menyempurnakan, kesempurnaan yang memuliakan Yesus Kristus ${ }^{26}$ Salah satu anugerah yang diberikan Allah kepada umat-Nya adalah pernikahan, yang akan didapatkan oleh lakilaki dan perempuan dewasa. Oleh kaerena itu sebelum pasangan yang mengambil keputusan untuk menikah hal yang harus dipahami bahwa anugerah kasih ini tidak boleh tercela dengan sesuatu yang menyakitkan hati Allah. Allah menginginkan semua pasangan tetap bersama, bahagia dan selaras dengan keinginan Allah yang menganugrahkan kasih kepada semua manusia.

\section{Dasar Pernikahan Adalah Firman}

Pernikahan merupakan sesuatu yang indah, sesuatu yang kudus dan mulia, tetapi bukan berarti ketika pasangan sudah menikah semua akan berjalan dengan indah. Banyak sekali pasangan yang diperhadapkan dengan masalah-masalah kehidupan. Masalah anak, keluarga, adat, pendidikan, pilihan, tata cara mengaturan uang, pengaturan menu dan lain sebagainya. Banyak masalah yang harus di hadapi dan dijalankan salah satunya masalah yang timbul adalah masalah adat dan budaya seperti yang sedang dibahas. Dalam hal ini untuk

\footnotetext{
${ }^{24}$ Bruce H.Willknison, A Biblicalleh Portrait OF Marrige ( Bandung: Gereja Bala Keselamatan, 2003), 1-3.

${ }^{25}$ Keith R, Inilah Jodohk u (Yogyakarta: Gloria Graffa, tt), 18-19.

${ }^{26}$ Wright, So You're Getting Merried (Yogyakarta: Gloria Graha, 2008), 138.
} 
mendapatkan pertolongan hikmat, kebijksanaan bahkan berkat berumah tangga, hal yang harus dilakukan oleh pasangan atau keluarga itu adalah dengan datang kepada Allah karena Ialah yang menciptakan pernikahan tersebut. ${ }^{27}$

Dengan pernikahan membuat suami istri menjadi satu keluarga yang hidup bersama dalam hubungan atau ikatan yang mempersatukan membangun rumah tangga merupakan suatu pilihan bagi setiap individu bagi suatu keluarga ketika memutuskan untuk bersama mutlak dasarnya firman Allah. ${ }^{28}$ Idealnya semua keluarga haruslah menjadikan Firman Tuhan sebagai pedoman hidup dalam menjalan apa saja di dalam kehidupan berkeluarga. Standar tertinggi dalam pernikahan Kristen yaitu iman percaya yang dibentuk oleh Firman Allah yang terus harus dilakukan dan ditaati. Oleh semua pihak keluarga ${ }^{29}$ Pernikahan Kristen memilki kesamaan dengan pernikahan non-Kristen atau dalam pernikahan adat sekalipun. Semua mengharapkan kebahagian keluarga, semua mengharapkan kekayaan dan semua mengharapkan keharmonisan. Namun perbedaan yang signifikan adalah dasar iman Kristen.

Jika Firman Allah mejadi dasar tertinggi suami istri, itulah hal yang paling tepat dilakukan oleh pasangan suami istri. Ketika nantinya dikaruniai anak maka seluruh keluarga harusnya memakai dasar ini untuk diajarkan kepada anak-anak bahwa dasar dalam berkeluarga adalah Firman Tuhan yang utuh. Barometer atau disebut tolok ukur semua keluarga untuk menjalani kehidupan dan dasar dalam mengambil tindakan.

\section{Tujuan Pernikahan Kristen adalah Kebahagian Keluarga}

Hubungan keduanya yang membentuk kebersamaan pernikahan; karena pernikahan merupakan panggilan Allah yang mulia. Artinya adalah pernikahan merupakan suatu kebersamaan untuk memenuhi kebutuhan manusia antara lain, sebagai teman, sebagai sahabat, saling mendampingi, pelayan atau saling melayani, menerima, serta berkorban satu dengan yang lainnya. ${ }^{30}$ Berkorban bagi keluarga merupakan suatu keharusan, karena pernikahan bukanlah hanya istri saja atau suami saja melainkan keluarga tersebut menjadisatu kesatuan yang utuh dan seimbang.

Pernikahan Kristen dibangun atas dasar tunduk kepada Firman Tuhan sebagai pedoman di dalam kehidupan bersama suami istri. Ajaran yang menjadi landasan keduanya adalah menerima Tuhan dan juruslamat, keduanya harus memiliki komitmen yang terus diasah setiap hari. Artinya iman itu harus berproses agar pernikahan tetap ada dalam kebahagian barsama Tuhan. ${ }^{31}$ Iman seseorang sangat mempengaruhi apa yang dikatakan

\footnotetext{
${ }^{27}$ Joyce Coon, Isaac dan Margaret Sembiri, Rencana Allah Bagi Rumah Tangga Kristen ( Bandung : Kalam Hidup, 1978), 9.

${ }^{28}$ Paulus Lilik Kristianto, Prinsip dan Praktek Pendidikan Agama Kristen ( Yogyakarta: ANDI,2006), 140.

${ }^{29}$ Billy Joe Daugherty, Pernikahan yang Kokoh (Jakarta: Metanoia Publishing, 2006), 55.

${ }^{30}$ Adam Hamilton, Bersamamu Selamanya ( Yogyakarta: Gloria Graffa, 2009), 28.

${ }^{31}$ Lon Ams, dkk, Menjadi Suami yang Andal: Paduan Praktis Bagi Anda yang Sudah Bertunagan dan Sudah Menikah (Yogyakarta: ANDI 2009), 63.
} 
dilakukan artinya iman sangat mempengaruhi pola hidup seseorang. ${ }^{32}$ Iman juga membawa seseorang untuk melakukan sesatu, iman menjadi filter bagi setiap orang mengambil suatu keputusan dalam kehidupannya secara pribadi.

Sedemikian pentingnya iman sebagai landasan untuk suami istri hidup bersama, oleh sebab itu ketika sudah tidak ada lagi iman maka sia-sialah hubungan yang dibangun karena tidak ada saling menerima saling mengasihi dan saling mengasihi. ${ }^{33}$ Iman setiap pribadi tidak dapat diukur oleh siapun, karena sangat pribadi antara pelaku dengan Allah. Jika pasangan suami istri sudah di persatukan oleh Allah maka seharusnya hubungan ini menjadi satu dan hubugan yang erat dengan Allah baik dari istri atau suami. Sebagian besar orang percaya memiliki pemikiran bahwa tujuan dari keluarga adalah melakukan perintah agama sehingga ketika melukakan perintah agama dan mendapatkan berkat. ${ }^{34}$ Berkat yang dimaksud dalam pernyataan ini adalah bekat keseluruhan, berkat yang dinikmati oleh seluruh keluarga dalam satu kesatuan yang utuh. Setiap keluarga mengharapkan kebahagian sejati, kebahagian yang senantiasa diharapkan pasangan suami istri.

Demikian yang dikatakan oleh adat ketika suami istri sudah melakukan pernikahan Mangadati secara adat Batak Toba, maka keluarga tersebut sangat menghargai orang tua. Menghormati orang tua merupakan perintah Allah bagi semua orang (Ef. 6:2). Keluarga besar dan memiliki tanggung jawab yang besar terhadap adat sehingga otomatis mendapat pasu-pasu atau berkat. Kata hormatilah (Yunani: tima) adalah perintah yang kedua yang sejajar dengan kata taat pada ayat sebelumnya. Kata tima mengandung arti menghormati, yang secara literal berarti: menetapkan harga, memberikan bantuan. Secara konteks memiliki arti menghormati, memberikan dukungan keuangan, memberikan penghargaan. Artinya penting bagi setiap orang untuk terus menerus membeikan penghargaan kepada orang tuannya. Keluarga merupakan lembaga yang senantiasa percaya kebenaran Firman Tuhan dan melakukan Firman itu senantiasa.

Pentinganya keluarga menurut orang percaya adalah untuk meneruskan keturunan untuk memberikan perlindungan, kenyamanan dan untuk memenuhi segala kebutuhan dan saling terbuka serta saling mengasihi. ${ }^{35}$ Sebagai orang percaya, seharusnya bertindak seperti murid Yesus yang harus mengasihi keluarga dan juga sesama. Pernikahan adat dalam hal ini adat Batak Toba mangadati masih dilakukan oleh keluarga Batak yang memiliki tujuan baik, supaya keluarga bisa menghormati orang tua, berbahagia dan senantiasa diberkati. Kebahagian sejati adalah kebahagian yang hanya bisa diberikan oleh kehadiran Tuhan Yesus di tengah-tengah keluarga yang senantiasa mengandalkan Tuhan dalam seluruh kehidupannya. Ketaatan merupakan kehendak Allah kepada manusia, kehendak Tuhan Allah yang memerintahkan agar anak-anak mentaati orang tua di dalam Tuhan, sehingga ketaatan kepada orang tua pada pihak anak-anak ini sebenarnya adalah ketaatan kepada

\footnotetext{
${ }^{32}$ Tu'u Etika dan pendidikan sosial ( Bandung: Kalam Hidup, 1990), 27.

${ }^{33}$ Sam Kamaleson, Berbahagialah Menikah ataupun membujang (Bandung: Kalam Hidup, 1987), 7

${ }^{34}$ T. Gilarso, Keluarga sebagai Fokus (Yogyakarta: Kanasius, 1996), 18.

${ }^{35}$ Wolfgang Simson, Gereja dunia yang mengubah Dunia (Jakarta: Metanoia 2003), 73.
} 
Tuhan. ${ }^{36}$ Ketaatan merupakan hal yang sangat menyenangkan hati Allah Allah, sehingga berkat dari ketaat keluarga adalah kebahagian keluarga.

\section{Revansi Pernikahan Adat Mangadati Suku Batak Toba}

Filosofi tentang "Juhut ni boru" : Mengikuti adat Batak "Hosa do alini hosa", artinya: Kalau kita mengambil yang bernyawa maka kita akan mengembalikan dengan yang bernyawa pula. Jadi kalau kawin anak kita laki-laki maka dia akan meminang anak perempuan dari marga lain (kalau menurut hukum diatas maka akan diganti pula dengan orang) tetapi itu mustahil maka digantilah dengan hewan (kerbau, lembu atau kambing dan babi bagi yang beragama Kristen). Jadi, hewan itu menjadi ganti tubuh/daging dari anak perempuan yang diambil (lamar). Karena itulah dinamakan "mangan juhut ni boru, dan itu pula sebabnya wanita tersebut tidak boleh memakan daging tadi, begitu juga pihak laki-laki tidak ikut sebagai parjambar.

\section{Melakukan Mangadati dengan Kasih}

Alasan mengapa orang Batak harus melakukan adat, salah satu jawabannya adalah, karena adanya holong (kasih); kasih kepada orang tua yang tentu juga meninggalkan warisan yang terbaik. Salah satu warisan itu adalah adat, kasih yang yang dicerminkan melalui keaktifan melakukan dan melestarikan adat, khususnya adat Batak Toba, peninggalan natua-tua na jolu (orang tua-tua dulu atau nenek moyang orang Batak). Sebagaian besar masyarakat Batak melakukan adat karena kecintaan kepada orang tua yang sudah melahirkan, membesarkan dan memberikan cinta dan kasih kepada anak-anaknya. Namun harus disadari oleh setiap orang tua dan anak bahwa sebenarnya tanda kasih yang terbesar orang tua kepada anak adalah kasih. Mengajarkan kasih itu kepada anak bahwa kasih yang diberikan orang tua bersumber dari kasih Allah yang sejati yang di berikan kepada umatnya. Kasih itu juga yang mendasarkan orang tua untuk diberikan kepada anak dan dengan kasih itu juga anak atau keturunannya melakukan kasih, salah satu ujud kasih itu adalah adat. Atat yang akan diacarkan, di teruskan untuk di lakukan.

Dalam kebenaran Fiman Tuhan dikatakan bahwa tugas mengajarkan tentang Allah serta perintahNya adalah, pertama-tama, tugas orang tua. Menurunkan segala yang baik, mengajarkan segala dasar atau aturan-aturan itu salah satu janji yang diucapkan pada pernikahan, menjadi kewajiban untuk mendidik anak, membesarkan, memenuhi kebutuhannya serta memberikan pengetahuan akan ketaatan kepada Allah. Ketaatan kepada Allah yang seharusnya diajarkan sebagai pedoman hidup orang percaya. Oleh sebab itu ketika seseorang taat kepada Allah maka akan tercermin kepada sesama. Ketaatan kepada sesama bisa kepada orang tua, kepada keluarga dan kepada orang lain. Dalam hal ini melakukan adat merupakan suatu ujud kasih dari ketaatan kepada Tuhan untuk sesama.

Melakukan acara adat dalam pernikahan mangadati merupakan suatu ketaatan dan memberikan pengharapan bagi masyarakat pelaku adat yang disebut dengan hasangapon. Adat istiadat tersebut memang lahir dalam masa kekafiran. Akan tetapi tidak mustahil manfaat-manfaat positifnya dapat disempurnakan oleh iman kepercayaan kekristenan

\footnotetext{
${ }^{36}$ Autrey Jarry, Surat Kiriman Penjara, (Malang: Gandum Mas 1988), 141 .
} 
dalam Tuhan Yesus Kristus. Jika setiap masyarakat Batak Toba mampu menerapkan pernikahan mangadati untuk mengejar tujuan penerimaan dan kebahagiaan, lembaga gereja akan lebih mudah mendampingi jemaatnya yang bersuku Batak untuk juga mengejar pengharapaan. Pengharapan yang sempurna di dalam hidup orang percaya dalam iman yang melakukan adat mangadati. Adat sebenarnya tidak perlu diperdebatkan atau dipertentangkan dengan iman percaya kepada Tuhan. Sebaiknya ketegangan di antara keduanya adalah memelihara keduanya secara positif, kreatif, kondusif, demi mempertinggi kualitas iman dan kualitas kultural masyarakat Batak Toba Kristen. ${ }^{37}$ Jika sudah demikian maka adat Batak Toba dan iman Kristen dapat berjalan dnegan harmonis di tengah-tengah masyarakat Batak Toba.

\section{Mangadati sebagai Cara Menghormati Orang tua}

Pelaksanaan adat pernikahan yang disebut dengan mangadati adalah salah satu sikap menghormati orang tua, yang dilakukan oleh anak. Artinya anak yang malakukan adat mangadati merupakan anak yang menjunjung harkat dan martabat keluarga (orang tua). Mengajarkan merupakan suatu perintah bagaimana sikap seorang anak kepada orang tuanya, taat, dan hormat merupakan suatu perintah dilakukan dalam wakru yang sama dan memiliki nilai yang sama. Pada saat seorang anak taat kepada orang tua, maka saat itu juga anak menghormati orang tua. Jadi taat dan hormat tidak dapat terpisahkan.

Suatu kenyataan bahwa adat Batak tetap dilaksanakan oleh sebagian besar orang Batak, di mana pun berada, sangat menghormati orang tua yang sudah melahirkan, membesarkan dengan kasih dan mencukupi setiap kebutuhan sesuai dengan kemampuan. Firman Tuhan dalam Efesus 6:1-3 dilakukan tanpa mengurangi ketekunannya dalam mengikuti aturan-aturan gereja sebagai orang Kristen. Bagi orang Batak yang masih memegang adat, menjadi orang Kristen yang taat tidak harus melepaskan identitasnya sebagai orang Batak. Pelaksanaan adat akan menjadi suatu yang sangat membahagian keluarga untuk dilakukan, dan berdampak kebahagian bagi keluarga dan yang sangat penting pelaksanaan adat mangadati membawa rasa hormat yang besar kepada orang tua dan keluarga besar.

\section{Mangadati adalah Melestarikan Adat}

Kecintaan terhadap adat merupakan bagian yang terus bergandengan dengan kecintaan kepada Tuhan. Identitas merupakan kebanggan bagi orang Batak untuk melakukan adat, namun dengan identitas tersebut selalu tercermin kebanggaan bahwa orang Batak haruslah melakukan adat dengan kesadaran dari hati nurani, artiya melakukan dnegan kasih bukan dengan paksa. Menerapkan adat dengan hati dan pikiran serta kehendak yang diperbaharui dan dikontrol sejauh yang disadari melalui penyataan Allah. ${ }^{38}$ Allah itu di atas budaya, Allah adalah awal budaya dan melalui budaya pula Allah menggunakan elemen-elemen kebudayaan untuk berinteraksi dengan manusia.

\footnotetext{
${ }^{37}$ Sagala Mangapul, Injil dan Adat Batak (Jakarta: Yayasan Bina Dunia, 2008), 62.

${ }^{38}$ Oliver, Akal Budi
} 
Sebenarnya perlu disadari bahwa sebagai manusia, seseorang tidak bisa memaksakan suatu kehendak kepada orang lain untuk melakukan apa yang di katakan adat dan budaya. Tetapi sebagai orang percaya seharusnya menyatakan suatu kebenaran melalui apa saja yang menjadikan semua yaitu Tuhan. Itu sebabnya bila seseorang dibaharui Allah, maka inti kebudayaannya juga ikut dibaharui (Band: I Kor. 5:17). ${ }^{39}$ Perubahan adat sangat diperlukan, jika adat tidak sesuai dengan kebenaran Firman Tuhan maka masyarakat yang hidup dalam kebenaran Firman Tuhan sebagai pelaku adat yang tunduk kepada kebenaran Firman Tuhan akan merubahnya. Artinya memperbaharui nilai adat merupakan kewajiban orang percaya. Sehingga setiap masyarakat Batak Toba yang memiliki kerinduan untuk terus melestarikan adat, harus hidup dalam kebenaran Firman itu.

Adat Batak Toba juga harus diubahkan dalam pikiran dan pola melakukan adat. Adat memang merupakan hal yang harus dipilih oleh keluarga artinya tidak semua adat sesuai dengan nila-nilai luhur kebenaran Firman Tuhan, oleh sebab itu seseorang atau masyarakat Batak hendaknya memiliki kepekaan rohani yang sangat baik. Adanya hubungan yang baik antara manusia dengan Allah untuk mencapai tujuan yang baik berdasarkan standar Allah.

Budaya Batak Toba dalam hal mangadati adalah suatu hasil karya manusia yang tidak bebas dari sentuhan dosa manusia. Meski demikian sebaiknya sebagai masyarakat Batak Toba hendaknya tidak mempertentangkan ini sehingga hasil kebudayaan dilihat sebagai bersifat kristen. Semua harus dinilai dari sudut pandang yang menyenangkan Allah dan apa yang tidak menyenangkan Allah. Adat dan budaya Batak Toba harusnya dinilai dari tingkat kesuaian dengan kehendak Allah. Dengan dasar sudut pandang Allah maka terujud melestarikan adat. Adat bukanlah hal yang kekal, namun dengan adat cara manusia menggunakannya dapat bernilai kekal.

\section{Mangadati sebagai Mengasihi Sesama}

Melakukan adat, merupakan hal yang sulit terpisahkan oleh masyarakat Batak dimana pun berada. Tempat bukanlah menjadi penghalang untuk masyarakat Batak melakukan adat. Karena ada banyak masyarakat yang sudah merantau dari bona pasogit (kampung halaman) ikatan kasih yang terjalin dari keluarga yang semarga, membuat orang Batak selalu merasakan kehangatan, walau bukan keluarga langsung satu darah. Melakukan adat mangadati pernikahan adat suku Batak Toba terdapat hubungan antara sesama yang menunjukan adanya kasih. Unsur kasih menjadi suatu hal yang menonjol dalam acara adat ini. Oleh sebab itu dalam Matius 22:40 disebutkan bahwa manusia mengasihi sesamanya seperti mengasihi diri sendiri. Mengasihi Allah tidak mungkin dipisahkan dengan mengasihi sesama manusia.

Adat dilakukan bukan hanya untuk penerimaan atau harga diri saja di lingkungan masyarakat sesama Batak, melainkan melalui penciptaan maupun pemeliharaan. Setiap pribadi tentulah merasa nyaman dan senang apabila kehadirannya di terima oleh orang lain di sekitarnya. Penerimaan pada setiap pribadi merupakan hal kebutuhan. Jika berbicara

\footnotetext{
${ }^{39}$ Tomatala, Teologi Kontekstualisasi: Suatu Pengantar (Malang: Gandum Mas, 1993), 79.
} 
kebutuhan artinya aalah sesuatu yang sangat penting. Namun bukan berarti penerimaan itu yang menjadi tolak ukur dalam seseorang berkreasi dalam budaya. Allah telah berikan kepada manusia karunia-karunia artistic dan kebudayaan untuk memungkinkan manusia menciptakan kebudayaan yang bervariasi dan kaya untuk kepentingan manusia selama berada di dunia ini. ${ }^{40}$ Sebaiknya setiap masyarakat Batak sadar akan pernyataan ini. "Kebudayaan tidak bernilai kekal, namun bisa dipergunakan untuk tujuan kekal. Manusia telah jatuh ke dalam dosa, dan sebagian mengandung unsur kuasa gelap. ${ }^{41}$ Pernyataan ini mengarahkan masyarakat Batak Toba untuk tidak menolak adat atau menerima semuanya, melainkan harus bersikap selektif. Keluarga haruslah menjadi sensor yang paling penting untuk bersikap kepada adat. Karena pelaku adat itu sendiri adalah manusia yang juga memiliki keterbatasan pikiran, keterbatasan kemampuan dan keterbatasan pengetahuan dalam melaksanakan adat.

Perintah Yesus kepada manusia untuk saling mengasihi Allah dan mengasihi sesama manusia. Jika manusia mengasihi Allah maka seharusnya yang lahir dari hati nurani seseorang haruslah mengasihi sesama manusia. Ini menunjukan bahwa kesatuan batin antara kasih kepada Allah dan kasih kepada manusia. ${ }^{42}$ Oleh sebab itu, sebagai orang percaya hendaknya dasar kasih menjadi bagian yang tidak terpisahkan dari hidup karena kasih (holong) harus jadi bagian yang tidak terpisahkan oleh manusia. Jika demikian seseorang mengasihi Allah tapi dia tidak mengasihi manusia atau sesama, maka dia disebut pendusta (1 Yoh 4:20). Kasih adalah dasar pelaksanaan adat; kasih kepada Tuhan dan kepada sesama.

\section{Kesimpulan}

Budaya dan adat merupakan anugerah Allah dalam hidup setiap manusia. Alkitab memandang kebudayaan sebagai suatu hal yang positif dan negatif. Oleh sebab itu jika budaya didukung oleh mandat budaya maka manusia akan berkreasi, sejalan dengan Firman Tuhan Kejadian 1:28. Selain nilai positif harus di ingat bahwa tidak semua kreasi manusia itu positif. Oleh sebab itu Firman Tuhan haruslah menjadi dasar dari setiap pelaksanaan adat mangadati suku Batak Toba. Kasih adalah dasar dari pelaksanaan tradisi mangadati, yang artinya kebenaran firman Tuhan harus diberitakan dalam budaya dan kegiatan adat. Mengasihi Allah tidak mungkin dipisahkan dengan mengasihi sesama manusia. Kasih terhadap Allah menjadi nyata dalam kasih terhadap sesama sehingga kasih terhadap sesama merupakan perwujudan kasih terhadap Allah.

Nilai-nilai negatif dalam pelaksanaan adat mangadati sebaiknya bisa dikikis secara bertahap dan terus-menerus sehingga menghasilkan nilai-nilai positif yang dapat dimanfaatkan untuk meningkatkan pelayanan dimana pun berada, baik di tengah-tengah masyarakat Batak Toba yang mangadati, juga masyarakat Batak Toba yang tidak melakukannya.

\footnotetext{
${ }^{40}$ Barcay Oliver R., Akal Budi Kristiani Bukan hanya Soal Intelek, (Malang: Gandum Mas, 1993), hal. 228, Cet 1

${ }^{41}$ Segala. Injil dan Adat Batak, hal. 58

${ }^{42}$ Verkuyl J., Etika Kristen : Bagian Umum (Jakarta: BPK Gunung Mulia, Cet 19, 2004), 140.
} 
Dalam pelaksanaan adat mangadati pernikahan suku Batak Toba bukanlah sesuatu yang bertentangan dengan iman percaya, namun tetap harus ada transformasi pada pelakunya sehingga budaya tidak menyimpang dari ajaran Kristus dan terus memancarkan kebenaran kasih dan iman dalam diri pelaku adat tersebut. Masyarakat yang mangadati adalah masyarakat yang senantiasa ingin memajukan budayanya, menjunjung tinggi hasil peninggalan dari leluhur. Bangsa yang besar adalah bangsa yang bisa menghargai pahlawan atau orang sebelumnya yang bisa menghargai serta mempertahankannya. Masyarakat yang mangadati masyarakat yang bisa memberikan pelajaran yang baik kepada generasi selanjutnya dan memberikan nilai-nilai yang baik kepada adat tersebut untuk dilestarikan.

\section{Referensi}

Ams, Lon., dkk, Menjadi Suami yang handal, Yogyakarta: Paduan Praktis Bagi Anda yang Sudah Bertunangan dan Sudah Menikah 2009.

Bukit, Pilemon. "Pandangan Kristen Tentang Kebudayaan Dan Adat Istiadat Di Dalamnya." SOTIRIA (Jurnal Theologia dan Pendidikan Agama Kristen) 2, no. 1 (2019): 1-15.

Daugherty, Billy Joe Pernikahan yang Kokoh, Jakarta: Metanoia Publishing 2006. Friesen, Inikah Rasanya Jatuh Cinta, Yogyakarta: Gloria Graffa, 2006.

Hadikusuma, Hilman Hukum Perkawinan Adat, Jakarta: Perlindungan adat Batak, 2000. Hamilton, Adam. Bersamamu Selamanya, Yogyakarta: Gloria Graffa, 2009.

Hutagaol, Firman Oktavianus, and Iky Sumarthina P. Prayitno. "Perkembangan Ritual Adat Mangongkal Holi Batak Toba Dalam Kekristenan Di Tanah Batak (The Development of the Mangongkal Holi Batak Toba Indigenous Ritual in Christianity in the Batak Land).” Anthropos: Jurnal Antropologi Sosial dan Budaya 6, no. 1 (2020): 84-92.

Isaac, Joyce Coon. dan Margaret Sembiri, Rencana Allah Bagi Rumah Tangga Kristen Bandung : Penerbit Kalam Hidup, 1978.

Kamaleson, Sam Berbahagialah Menikah ataupun membujang, Bandung: Kalam hidup 2003.

Koentjaraningrat, Manusia dan Kebudayaan di Indonesia Jakarta Djambatan Cet 10, 1985.

Kristianto, Paulus Lilik. Prinsip dan Praktik Pendidikan Agama Kristen, Yogyakarta: ANDI 2006.

Lothar, Schreiner. Adat dan Injil, Perjumpaan Adat dengan Iman Kristen Di Tanah Batak, Jakarta:BPK Gunung Mulia 2002.

Marbun, M A, Kamus Budaya Batak Toba, Jakarta :Balai Pustaka, 1987.

Nainggolan, Togar. “Adat Dan Iman Kristen Di Tanah Batak.” Jurnal Filsafat-Teologi 5, no. 1 (2007): 75-93.

Napel, Jalan yang Lebih Utama Lagi, Jakarta: 2010

Nasution, S. Metode Reseach, Jakarta: Bumi Aksara, 2003.

Nazir, Metode Penelitian, Jakarta: Ghalia Indonesia, 2003.

Octavianus, Petrus. Membangun rumah tangga yang bahagia, Batumalang: Yayasan persekuatuan pekabaran injil indonesia departemen literatur 2003.

Purba, Mauly. "Gereja Dan Adat: Kasus Gondang Sabangunan Dan Tortor." Antropologi Indonesia 62, no. 1 (2014): 25-41.

R, Keith inilah Jodohku. Yogyakarta: Gloria Grrafa, 1993.

Sagala, Mangapul. Injil dan Adat Batak, , Jakarta: Yayasan Bina Dunia Cet 2, 2008.

Sihombing, TM Jambar Hata, Jakarta:CV Tulus Jaya 1989.

Sasmoko. Penelitian Eksplanatori ndan Konfirmatori, Sorong:UKIP, 2011. 
Siahaan, SR. Aha do Adat, Yogyakarta: 2012.

Suryabrata, S. Metodologi Penelitian, Jakarta: PT Raja Grafindo. 2000.

Susmanto, Pembahasan Terpadu Statistik dan Metodelogi Riset, Yogyakarta: Andi Yogyakarta, 2002.

Sarumpaet, J,P Kamus Batak Indonesia, Jakarta: Erlangga 1995

Sinaga, Richard Meninggal Adat Dalihan Natolu, Jakarta : Dian utama, 2003.

Sirait, Destien Mistavakia, and Dasrun Hidayat. "Pola Komunikasi Pada Prosesi Mangulosi Dalam Pernikahan Budaya Adat Batak Toba.” Jurnal Ilmu Komunikasi 2, no. 1 (2016): 23-31.

Supranto, J . Ma, Metode Riset, Jakarta: Lembaga Penerbit Fakultas Ekonomi Universitas Indonesia, 1991.

Trisna, Jonathan A Pernikahan Kristen Suatu Usaha Dalam Kristus, Jakarta: institut keguruan Indonesia, 2000.

Tobing O. L., The Structure Of The Toba - Batak Belief sIn The High God, Jakarta: South and South-East Celebes Institute For Culture, Cet .3 1994.

Tomatala, Teologi Kontekstualisasi Suatu pengantar, Malang: Gandum Mas, Cet 11993.

T. Gilarso Keluarga sebagai Fokus Yogyakarta Kanisius 1996.

Tu'u Etika dan pendidikan sosial ( Bandung Kalam Hidup.

Utrecht, E. Pengantar Dalam Hukum Indonesia, Pen. dan Balai Buku “Ichtiar”, Jakarta: Cet.IX, , 1996

Vergouwen, J. C., Masyarakat dan Hukum Adat Batak Toba, Pustaka Azet, Jakarta: Cet 1, 1985

Verkuyl. Etika Kristen, Jilid 1, Jakarta: BPK Gunung Mulia 1993.

Volkard dan Gertindescheuneman, Hidup Sebelum Dan sesudah nikah, Malang: Yayasan persekutuan Injil Indonesia Literatur 1978.

Wolfgang simson, Gereja dunia yang mengubah dunia, Jakarta metanoia 2003.

Wright, So You're Getting Merried, Yogyakarta: Gloria Graha, 2008.

Wetboek, Burgerlijk Ordonasi Perkawinan Indonesia Kristen, Jakarta: Huwelijks Ordonatie Christen Indonesier S. 1933 